\title{
Aktivitas Antioksidan Jus Stroberi (Fragaria ananassa Duchessne) Terhadap Kadar SGPT, SGOT dan MDA pada Tikus Jantan Galur Wistar yang Diinduksi Isoniazid
}

\author{
Ebta Narasukma Anggraeny'), Endang Sri Sunarsih'2), \\ Patricia Sanggita Listyoputri Wibowo ${ }^{1)}$, Novi Elisa ${ }^{1)}$ \\ ${ }^{1)}$ Sekolah Tinggi Ilmu Farmasi Yayaysan Pharmasi, Semarang \\ ${ }^{2}$ Universitas Diponegoro, Semarang \\ sukma.anggraeny@gmail.com
}

\begin{abstract}
ABSTRAK
Isoniazid adalah obat anti tuberkulosis yang digunakan baik sebagai monoterapi atau kombinasi. Penggunaan isoniazid dalam waktu lama dapat menyebabkan hepatotoksik. Hepatotoksik disebabkan oleh hasil metabolisme isoniazid di hepar berupa hidrazin dan asetilhidrazin. Radikal bebas tersebut yang menyebabkan tingginya reactive oxygen species (ROS) di dalam tubuh. Tingginya radikal bebas menyebabkan peningkatan kadar SGPT dan SGOT yang merupakan indikator adanya kerusakan hepar. Tingginya radikal bebas dalam tubuh dapat dilihat dari paramter MDA. Hal tersebut dapat diatasi dengan pemberian antioksidan eksogen seperti jus stroberi (Fragaria ananassa Duchessne). Tujuan penelitian ini untuk mengetahui skrinning fitokimia jus stroberi dan pengaruh pemberian jus stroberi terhadap kadar SGPT, SGOT dan MDA pada tikus yang diinduksi Isoniazid. Perlakuan diberikan selama 14 hari dengan pembagian kelompok yaitu kontrol normal, kontrol negatif, kontrol positif, dosis $3 \mathrm{~g} / \mathrm{kgBB}, 6 \mathrm{~g} / \mathrm{kgBB}$, dan $9 \mathrm{~g} / \mathrm{kgBB}$. Pengambilan data dilakukan pada hari 1 , hari 15 , dan hari 29. Hasil penelitian dapat disimpulkan bahwa jus stroberi dapat menurunkan kadar SGPT, SGOT dan MDA pada tikus yang diinduksi isoniazid dengan dosis efektif sebesar $3 \mathrm{~g} / \mathrm{kgBB}$ tikus.
\end{abstract}

Kata kunci: Isoniazid; jus stroberi; SGPT; SGOT; MDA

Effect of Strawberry Juice (Fragraria ananassa Duchessne) against SGPT, SGOT and MDA levels in Isoniazide-Induced Wistar Male Rats

\begin{abstract}
Isoniazid is an anti-tuberculosis drug that is used either as monotherapy or in combination. Prolonged use of isoniazid can cause hepatotoxicity. Hepatotoxicity is caused by the hepatic isoniazid metabolism in the form of hydrazine and acetylhydrazine. These free radicals cause high reactive oxygen species (ROS) in the body. The high level of free radicals causes an increase in SGPT and SGOT levels, which are indicators of liver damage. The high level of free radicals in the body can be seen from the MDA parameter. This can be overcome by giving exogenous antioxidants such as strawberry juice (Fragaria ananassa Duchessne). The purpose of this study was to determine the phytochemical screening of strawberry juice and the effect of giving strawberry juice on the levels of SGPT, SGOT and MDA in rats induced by Isoniazid. The treatment was given for 14 days divided into groups, namely normal control, negative control, positive control, dose of $3 \mathrm{~g} / \mathrm{kg}, 6 \mathrm{~g} / \mathrm{kg}$, and $9 \mathrm{~g} / \mathrm{kg}$ of body weight. Data were collected on day 1 , day 15 , and day 29. The results of this study concluded that strawberry juice can reduce levels of SGPT, SGOT and MDA in isoniazid-induced rats with an effective dose of $3 \mathrm{~g} / \mathrm{kgBW}$ rats.
\end{abstract}

Keywords:Isoniazid; Strawberry juice; SGPT; SGOT; MDA

(Article History： Received 23-09-2020; Accepted 28-01-2021; Published 01-03-2021)

\section{PENDAHULUAN}

Masalah kesehatan semakin meluas dengan adanya beberapa penyakit yang berbahaya salah satunya penyakit tuberculosis
(TB). Tuberculosis adalah penyakit menular oleh infeksi bakteri Mycobacterium tuberculosis. Penyakit ini dapat menyebar melalui droplet oleh orang yang terinfeksi 
bateri tersebut. Isoniazid adalah obat antituberkulosis (OAT), baik sebagai monoterapi atau dalam kombinasi dengan obat TB lainnya (Rahman, 2013). Penggunaan isoniazid sebagai OAT dapat menyebabkan terjadinya drug induced liver injury (DILI) atau kerusakan hepatosit (Pillai et al., 2012).

Hepatotoksik akibat isoniazid disebabkan oleh reaksi radikal bebas dari hasil metabolisme isoniazid di hepar berupa hidrazin dan asetilhidrazin. Metabolit reaktif (asetilhidrazin dan hidrazin) akan memicu terjadinya asetilasi makromolekul yang menyebabkan terjadinya protein binding di hepar dan penurunan aktivitas glutation yang merupakan pendetoksifikasi reactive oxygen species (ROS). Kedua mekanisme tersebut akan mengakibatkan peroksidasi lemak dan gangguan sintesis protein sehingga terjadi kerusakan hepatosit (Lian et al., 2013).

Indikasi adanya kerusakan pada hepar adalah dengan terlepasnya enzim SGPT dan SGOT ke dalam serum. SGPT paling sering digunakan sebagai parameter kerusakan hepar karena SGPT dihasilkan oleh hepar. SGOT terdapat pada hepar, otak, ginjal, otot rangka, dan jantung. Oleh karena itu SGPT dan SGOT sering digunakan sebagai indikator adanya kerusakan hepar (Peanasari et al., 2015).

Peningkatan kadar SGPT dan SGOT di dalam darah dapat dipicu oleh adanya radikal bebas yang berlebihan di dalam tubuh. Kerusakan sel akibat radikal bebas pada dasarnya dapat diatasi oleh antioksidan endogen, namun apabila radikal yang terdapat di dalam tubuh berlebih, maka dibutuhkan antioksidan eksogen untuk menetralkan radikal bebas yang terbentuk (Reynertson, 2007).

Radikal bebas akan menginduksi terjadinya peroksidasi lipid. Peroksidasi lipid akan merusak sel karena strukturnya tidak stabil dan mencari pasangan elektron lainnya dari membran sel dengan cara memecah asam lemak tidak jenuh atau PUFA (poly unsaturated fatty acid) yang dapat menghasilkan MDA (malondialdehid). Biomarker adanya radikal bebas yang tidak dapat dinetralkan oleh antioksidan dalam tubuh adalah MDA (Ayala et al., 2014).

Salah satu antioksidan eksogen yang berasal dari alam adalah stroberi. Stroberi merupakan buah yang sering dikonsumsi oleh masyarakat dan mudah didapat. Stroberi memiliki kandungan antioksidan dan senyawa fenolik sebesar 243,3mg/kg-290,4mg/kg buah segar (Oszmiański \& Wojdyło, 2009). Kelas utama senyawa fenolik diwakili oleh flavonoid terutama anthocyanin (Kähkönen $e t$ al., 2001). Kemudian diikuti oleh tanin dan asam fenolat (Aaby et al., 2005).

Tujuan dari penelitian ini adalah untuk mengetahui skrinning fitokimia jus stroberi dan aktivitas antioksidan jus stroberi. Aktivitas antioksidan jus stroberi dapat dilihat dari kadar SGPT, SGOT, dan MDA pada tikus jantan galur wistar yang diinduksi Isoniazid. Dosis Isoniazid yang digunakan untuk induksi sebesar $200 \mathrm{mg} / \mathrm{kgBB}$ tikus.

\section{METODE PENELITIAN}

Penelitian ini merupakan penelitian eksperimental dengan rancangan Pre and Post test Randomized Control Group Design. Penelitian dilakukan pada bulan Februari 2020 sampai Juli 2020. Penelitian dilakukan di Laboratorium Farmakologi Sekolah Tinggi Ilmu Farmasi Yayasan Pharmasi Semarang. Penelitian ini sudah mendapatkan persetujuan etik nomor 094/CN/SW/KEPKSTIFAR/EC/I/2020.

\section{Bahan}

Bahan yang digunakan adalah buah stroberi, hewan uji tikus galur Wistar jantan, silika GF254, aquadestilata, isoniazid dari PT Phapros, Curcumin pa, CMC Na, 1,1,3,3tetrametoksipropana (TMP), trikloroasetat (TCA), asam tiobarbiturat (TBA), aquadestilata, asam asetat glasial, AST/ SGOT dan ALT/ SGPT Elitech Clinical System yang diperoleh dari Sekolah Tinggi Ilmu Farmasi Yayasan Pharmasi Semarang.

\section{Alat}

Alat yang digunakan dalam penelitian ini adalah timbangan (digital dan analitik), juicer, beaker glass, corong kaca, batang pengaduk, tabung sentrifuge, pipa kapiler, gelas ukur, kandang hewan, spuit injeksi dengan jarum berujung tumpul (sonde), sentrifuge (Gemmy centrifuge PLC-05), mikropipet, asbes, thermometer, statif, klem, Spektrofotometer UV-VIS, dan Spectrophotometric Mikrolab 300.

\section{Pembuatan Jus Stroberi}

Buah segar yang telah disortasi, dicuci, dibersihkan dari bagian daunnya kemudian ditimbang sesuai perhitungan. Buah dimasukkan ke dalam juicer dan sari 
ditampung dalam wadah. Sari jus buah stroberi dimasukkan ke dalam gelas ukur untuk mengetahui volume yang didapat. Sari jus stroberi dimasukkan ke dalam botol yang terlindung dari cahaya matahari dan disimpan di dalam lemari es.

\section{Skrinning Fitokimia Jus Stroberi}

meliputi:

Uji pendahuluan yang dilakukan

1. Flavonoid

Jus stroberi sebanyak $0,5 \mathrm{ml}$ dimasukkan ke dalam tabung reaksi, ditambah dengan serbuk $\mathrm{Mg}( \pm 100 \mathrm{mg})$ dan $1 \mathrm{ml} \mathrm{HCl}$ pekat, lalu ditambahkan amil alkohol ( $\pm 2 \mathrm{ml})$, gojog kuat-kuat dan dibiarkan hingga memisah, diamati perubahannya (Harborne, 1987). Adanya senyawa flavonoid ditandai dengan terbentuknya warna merah atau orange pada senyawa amil alkohol (Endarini, 2016).

2. Tanin

Jus stroberi sebanyak $0,5 \mathrm{ml}$ dimasukkan ke dalam tabung reaksi ditambahkan $\mathrm{NaCl} 10 \%$, kemudian disaring dan diambil filtratnya. Filtrat kemudian dibagi menjadi dua yaitu filtrat A dan B. Filtrat A ditambahkan gelatin $1 \%$. Hasil positif jika terbentuk endapan putih. Filtrat B ditambah larutan $\mathrm{FeCl}_{3} 10 \%$. Hasil positif terjadi warna hijau gelap atau hijau kebiruan (Endarini, 2016).

3. Saponin

Jus stroberi sebanyak $0,5 \mathrm{ml}$ dimasukkan ke dalam tabung reaksi, ditambahkan $10 \mathrm{ml}$ air panas, didinginkan dan kemudian dikocok kuat-kuat selama 10 detik. Reaksi positif jika terbentuk buih yang stabil selama tidak kurang dari 10 menit, setinggi 1 $\mathrm{cm}$ sampai $10 \mathrm{~cm}$. Pada penambahan 1 tetes asam klorida $2 \mathrm{~N}$ buih tidak hilang (Depkes RI, 1979).

4. Alkaloid

Jus stroberi sebanyak $0,5 \mathrm{ml}$ dimasukkan ke dalam tabung reaksi kemudian dicampur dengan $1 \mathrm{ml} \mathrm{HCl} 2 \mathrm{~N}$ dan $9 \mathrm{ml}$ aquadest panas. Larutan dipanaskan selama 2 menit, kemudian didinginkan dan disaring. Filtrate dimasukkan kedalam 2 tabung reaksi. Tabung pertama ditambahkan pereaksi Dragendroff dan tabung kedua ditambahkan pereaksi Mayer (Depkes RI, 1995). Hasil positif alkaloid ditandai dengan terbentuknya endapan berwarna coklat kemerahan jika ditambahkan pereaksi Dragendroff dan terbentuk endapan putih jika ditambahkan pereaksi meyer (Endarini, 2016).

\section{Steroid dan Triterpenoid}

Jus stroberi sebanyak $0,5 \mathrm{ml}$ dimasukkan ke dalam tabung reaksi dicampur dengan eter, kemudian disaring dan diambil filtratnya. Filtrat tersebut diuapkan dalam cawan penguap hingga diperoleh residu. Residu ditambah 2 tetes asam asetat anhidrat dan 1 tetes asam sulfat pekat. Adanya senyawa golongan terpenoid ditandai dengan timbulnya warna merah sedangkan adanya senyawa golongan steroid ditandai dengan timbulnya warna biru (Endarini, 2016).

\section{Uji Penegasan atau KLT Jus Stroberi}

Fase diam yang digunakan adalah silika GF254 dan fase gerak yang digunakan meliputi :

1. Flavonoid

Eluen yang digunakan adalah n-butanol :asam asetat glasial :air (4:1:5). Eluen dijenuhkan lalu diambil fase n-butanol. Penampak bercak yang digunakan yaitu uap ammonia. Noda dengan warna kuning kecoklatan menunjukkan adanya kandungan flavonoid (Robinson, 1995).

2. Tanin

Eluen yang digunakan adalah toluene: etil asetat (3:1). Penampak bercak yang digunakan yaitu $\mathrm{FeCl}_{3}$. Noda dengan warna hijau kehitaman menandakan adanya senyawa tanin (Robinson, 1995).

3. Saponin

Eluen yang digunakan adalah kloroform: methanol: air (64:50:10). Penampak bercak yang digunakan yaitu anisaldehid asam sulfat kemudian dioven dengan suhu $100^{\circ} \mathrm{C}$ selama 5-10 menit. Warna hijau atau biru pada sinar tampak menunjukkan adanya senyawa saponin (Nuria et al., 2009).

\section{Alkaloid}

Eluen yang digunakan adalah etil asetat: metanol: air (100:13,5:10). Penampak bercak yang digunakan yaitu pereaksi dragendroff. Senyawa alkaloid akan membentuk warna coklat atau jingga (Arifin et al., 2006)

\section{Triterpenoid}

Eluen yang digunakan adalah toluen: etil asetat (93:7). Penampak bercak yang digunakan yaitu anisaldehida-asam sulfat. Lempeng dioven $110^{\circ} \mathrm{C}$ selama $5-10$ menit. Senyawa triterpenoid akan membentuk noda berwarna merah ungu, ungu tua, hijau biru, merah (Hayati et al., 2012). 


\section{Perlakuan Hewan Coba}

Penelitian ini dilakukan dengan menggunakan 30 ekor tikus dan dibagi menjadi 6 kelompok yaitu kelompok I (kontrol normal), kelompol II (CMC $\mathrm{Na} 0,5 \%)$, kelompok III (Curcumin 50mg/kgBB), kelompok IV $(3 \mathrm{~g} / \mathrm{kgBB})$, kelompok V $(6 \mathrm{~g} / \mathrm{kgBB})$, dan kelompok VI $(9 \mathrm{~g} / \mathrm{kgBB})$. Diukur kadar SGPT, SGOT dan MDA pada hari ke-1 atau sebelum perlakuan. Pada kelompok I diberikan pakan standart (rat bio) dan minum sedangkan pada kelompok II, III, IV, V, dan VI diberikan induksi isoniazid 200 $\mathrm{mg} / \mathrm{kgBB}$ selama 14 hari. Diukur kembali kadar SGPT, SGOT dan MDA pada hari ke15. Selanjutnya diberikan perlakuan sesuai kelompok masing-masing selama 14 hari. Diukur kadar SGPT, SGOT, dan MDA pada hari ke-29. Data yang diperoleh dianalisa menggunakan SPSS versi 19.

\section{Pengukuran Kadar MDA}

Plasma sebanyak $200 \mu \mathrm{l}$ di masukkan tabung centrifuge. Ditambahkan 1,0ml TCA $20 \%$ dan $1,0 \mathrm{ml}$ TBA $1 \%$. TBA dibuat dengan pelarut asam asetat glasial 50\%. Larutan kemudian divortex. Larutan diinkubasi selama 45 menit pada suhu $95^{\circ} \mathrm{C}$, lalu didinginkan. Larutan disentrifugasi dengan kecepatan 6000 rpm selama 15 menit. Supernatan dibagian atas diambil dan dimasukkan ke dalam tabung baru. Absorbansi sampel diukur menggunakan spektrofotometer UV-Vis pada $\lambda 532 \mathrm{mn}$ (Momuat et al., 2011).

\section{Pengukuran Kadar SGPT dan SGOT}

Pada pengukuran kadar SGPT dan SGOT menggunakan sampel berupa serum darah. Jumlah serum yang diukur sesuai dengan SOP pada Elitech Clinical System. Reagen yang digunakan yaitu AST dan ALT dari Elitech Clinical System. Alat yang digunakan yaitu Spectrophotometric Mikrolab 30.

\section{HASIL DAN PEMBAHASAN}

Hasil uji pendahuluan (skrinning fitokimia) dan KLT (Kromatografi Lapis Tipis) jus stroberi dapat dilihat pada Tabel 1.

Uji skrining fitokimia adalah untuk mengetahui senyawa metabolit sekunder yang terkandung dalam jus stroberi. Dari hasil pengujian diketahui jus stroberi positif mengandung flavonoid, alkaloid, tanin dan saponin. Senyawa yang paling banyak terkandung di dalam buah stroberi yaitu ellagitannin, antosianin dan flavonol. Flavonol yang diidentifikasi dalam buah stroberi yaitu turunan quersetin dan kaempferol (Aaby et al., 2007).

Table 1. Hasil Skrinning Fitokimia dan KLT

\begin{tabular}{ccl}
\hline Senyawa & \multicolumn{2}{c}{ Hasil } \\
\cline { 2 - 3 } & Skrinning & \multicolumn{1}{c}{ KLT } \\
\hline Flavonoid & + & Rf $1: 0,76$ \\
& & Rf $2: 0,59$ \\
\hline Alkaloid & + & Rf : 0,73 \\
\hline Tanin & + & Rf : 0,39 \\
\hline Saponin & + & Rf : 0.48 \\
\hline Steroid/ & - & Rf : - \\
Triterpenoid & & \\
\hline
\end{tabular}

(+) Menunjukkan hasil positif

(-) Menunjukkan hasil negatif

Jus stroberi diorientasi volume jusnya untuk mengetahui berapa besar volume yang didapat pada buah segar. Buah stroberi segar ditimbang sebanyak 30gr, lalu dijuicer. Hasil orientasinya yaitu dalam 30 gr buah stroberi menghasilkan volume jus sebesar 20,38 ml.

Uji aktivitas farmakologi dilakukan pada hewan uji. Uji ini dilakukan untuk mengetahui aktivitas antioksidan jus stroberi dalam menurunkan kadar SGPT, SGOT dan MDA. Kadar normal SGPT dalam darah yaitu 18-45 U/L (Giknis \& Clifford, 2008). Kadar normal SGOT pada tikus jantan yaitu 5,7-80,8 U/L (Mitruka \& Rawnsley, 1981).

Hasil pengukuran kadar SGPT, SGOT dan MDA pada semua kelompok dapat dilihat pada Tabel 2, 3, dan 4. Pada hari ke-1 menunjukkan kadar SGPT, SGOT dan MDA dalam keadaan normal. Pada hari ke-15 menunjukkan kadar setelah induksi Isoniazid dosis $200 \mathrm{mg} / \mathrm{KgBB}$ tikus. Pada Hari ke-29 menunjukkan kadar setelah pemberian jus stroberi. Peningkatan kadar pada hari ke-15 terjadi karena adanya radikal bebas. Radikal bebas ini berasal dari metabolisme isoniazid di hati.

Uji parametrik dilakukan pada persen penurunan kadar SGPT, SGOT, dan MDA. Uji parametrik ini menggunakan One-Way Anova dengan taraf kepercayaan 95\%. Hasil uji One-Way Anova untuk persentase penurunan kadar SGOT dan MDA menunjukkan adanya perbedaan kadar antara kelompok dengan hasil SGOT $\mathrm{p}=0,015$, dan MDA $p=0,000$. Pada SGPT menunjukkan nilai $\mathrm{p}=0,230$ berarti tidak ada perbedaan kadar antar kelompok. Pada penelitian ini dilakukan uji lanjut, yaitu uji Post-hoc LSD 
untuk melihat nilai signifikansi antar kelompok.

Hasil uji Post-hoc LSD pada kelompok kontrol positif dibandingkan dengan kelompok jus stroberi (Fragaria ananassa Duchessne) dosis $3 \mathrm{~g} / \mathrm{kgBB}, 6 \mathrm{~g} / \mathrm{kgBB}$, dan $9 \mathrm{~g} / \mathrm{kgBB}$ menunjukkan hasil signifikan. Hal tersebut menjelaskan bahwa jus stroberi dosis $3 \mathrm{~g} / \mathrm{kgBB}, 6 \mathrm{~g} / \mathrm{kgBB}$, dan $9 \mathrm{~g} / \mathrm{kgBB}$ mampu menurunkan kadar SGPT, SGOT, dan MDA tikus yang diinduksi Isoniazid sebanding dengan kontrol positif yaitu Curcumin pa dosis $50 \mathrm{mg} / \mathrm{kgBB}$ tikus. Hal ini menjadi dasar dalam pemilihan dosis efektif jus stroberi bahwa dosis 3g/kgBB merupakan dosis efektif untuk menurunkan kadar SGPT, SGOT, dan MDA tikus.

Tabel 2. Rerata \pm SD Hasil Pengukuran Kadar SGPT dan Persen Penurunan Kadar SGPT

\begin{tabular}{|c|c|c|c|c|c|}
\hline \multirow{2}{*}{ Kelompok } & \multicolumn{3}{|c|}{ Rerata \pm SD $(\mathbf{U} / \mathbf{l})$} & \multirow{2}{*}{$\begin{array}{c}\% \\
\text { Penurunan }\end{array}$} & \multirow{2}{*}{$\begin{array}{c}\text { Anova } \\
\text { (Sig.) }\end{array}$} \\
\hline & Hari 1 & Hari ke-15 & Hari ke-29 & & \\
\hline Kontrol Normal & $62,00 \pm 20,19$ & $74,40 \pm 10,29$ & $71,20 \pm 17,28$ & $5,25 \pm 11,40$ & \\
\hline $\begin{array}{l}\text { Kontrol Negatif } \\
(\mathrm{CMC} \mathrm{Na} 0.5 \%)\end{array}$ & $57,00 \pm 8,89$ & $70,80 \pm 27,52$ & $66,60 \pm 21,88$ & $4,07 \pm 9,77$ & \\
\hline $\begin{array}{l}\text { Kontrol Positif } \\
\text { (Curcumin } \\
50 \mathrm{mg} / \mathrm{KgBB})\end{array}$ & $38,20 \pm 7,19$ & $63,60 \pm 21,45$ & $46,80 \pm 4,38$ & $18,17 \pm 32,16$ & \\
\hline $\begin{array}{l}\text { Jus stroberi } \\
3 \mathrm{~g} / \mathrm{KgBB}\end{array}$ & $50,60 \pm 8,26$ & $73,00 \pm 18,92$ & $58,60 \pm 10,41$ & $15,47 \pm 24,04$ & 0,230 \\
\hline $\begin{array}{l}\text { Jus stroberi } \\
6 \mathrm{~g} / \mathrm{KgBB} \\
\text { Jus stroberi }\end{array}$ & $47,80 \pm 7,92$ & $75,20 \pm 21,28$ & $46,00 \pm 11,31$ & $35,11 \pm 20,43$ & \\
\hline $9 \mathrm{~g} / \mathrm{KgBB}$ & $54,80 \pm 11,90$ & $70,40 \pm 21,05$ & $56,40 \pm 15,47$ & $17,45 \pm 16,74$ & \\
\hline
\end{tabular}

Tabel 3. Rerata \pm SD Hasil Pengukuran Kadar SGOT dan Persen Penurunan Kadar SGOT

\begin{tabular}{|c|c|c|c|c|c|}
\hline \multirow{2}{*}{ Kelompok } & \multicolumn{3}{|c|}{ Rerata \pm SD (U/I) } & \multirow{2}{*}{$\%$ Penurunan } & \multirow{2}{*}{$\begin{array}{c}\text { Anova } \\
\text { (Sig.) }\end{array}$} \\
\hline & Hari 1 & Hari ke-15 & Hari ke-29 & & \\
\hline $\begin{array}{l}\text { Kontrol } \\
\text { Normal }\end{array}$ & $155,00 \pm 63,70$ & $141,20 \pm 30,93$ & $155,40 \pm 23,70$ & $-13,43 \pm 23,54$ & \\
\hline $\begin{array}{c}\text { Kontrol } \\
\text { Negatif } \\
(\mathrm{CMC} \mathrm{Na} \\
0.5 \%)\end{array}$ & $153,80 \pm 42,54$ & $197,40 \pm 39,74$ & $183,00 \pm 13,82$ & $5,40 \pm 12,52$ & \\
\hline $\begin{array}{c}\text { Kontrol } \\
\text { Positif } \\
\text { (Curcumin }\end{array}$ & $132,80 \pm 41,98$ & $178,60 \pm 81,14$ & $116,20 \pm 6,26$ & $25,94 \pm 25,56$ & 0,015 \\
\hline $\begin{array}{c}50 \mathrm{mg} / \mathrm{KgBB}) \\
\text { Jus stroberi } \\
3 \mathrm{~g} / \mathrm{KgBB}\end{array}$ & $150,00 \pm 45,11$ & $165,00 \pm 60,44$ & $116,20 \pm 13,92$ & $24,00 \pm 20,49$ & \\
\hline $\begin{array}{l}\text { Jus stroberi } \\
6 \mathrm{~g} / \mathrm{KgBB} \\
\text { Jus stroberi }\end{array}$ & $129,20 \pm 29,41$ & $226,20 \pm 70,98$ & $143,40 \pm 24,98$ & $32,, 29 \pm 21.45$ & \\
\hline $9 \mathrm{~g} / \mathrm{KgBB}$ & $159,60 \pm 30,48$ & $219,40 \pm 39,72$ & $175,20 \pm 6,57$ & $18,15 \pm 14,02$ & \\
\hline
\end{tabular}


Tabel 4. Rerata \pm SD Hasil Pengukuran Kadar MDA dan Persen Penurunan Kadar MDA

\begin{tabular}{|c|c|c|c|c|c|}
\hline \multirow{2}{*}{ Kelompok } & \multicolumn{3}{|c|}{ Rerata \pm SD $(\mu M)$} & \multirow{2}{*}{$\%$ Penurunan } & \multirow{2}{*}{$\begin{array}{c}\text { Anova } \\
\text { Sig. }\end{array}$} \\
\hline & Hari 1 & Hari ke-15 & Hari ke-29 & & \\
\hline Kontrol Normal & $50,9 \pm 5,74$ & $55,56 \pm 5,33$ & $54,37 \pm 1,10$ & $1,39 \pm 8,00$ & \\
\hline $\begin{array}{c}\text { Kontrol Negatif } \\
\text { (CMC Na } \\
0.5 \%)\end{array}$ & $48,09 \pm 11,04$ & $85,39 \pm 7,75$ & $76,78 \pm 6,40$ & $9,90 \pm 4,35$ & \\
\hline $\begin{array}{l}\text { Kontrol Positif } \\
\text { (Curcumin } \\
50 \mathrm{mg} / \mathrm{KgBB})\end{array}$ & $47,57 \pm 5,65$ & $75,73 \pm 7,63$ & $56,99 \pm 19,90$ & $24,98 \pm 8,29$ & \\
\hline $\begin{array}{l}\text { Jus stroberi } \\
3 \mathrm{~g} / \mathrm{KgBB}\end{array}$ & $47,04 \pm 5,85$ & $78,06 \pm 5,20$ & $59,65 \pm 5,27$ & $23,65 \pm 2,93$ & 0,000 \\
\hline $\begin{array}{l}\text { Jus stroberi } \\
6 \mathrm{~g} / \mathrm{KgBB} \\
\text { Jus stroberi }\end{array}$ & $47,90 \pm 4,41$ & $79,40 \pm 4,97$ & $52,18 \pm 6,19$ & $34,41 \pm 4,55$ & \\
\hline $9 \mathrm{~g} / \mathrm{KgBB}$ & $45,52 \pm 3,36$ & $77,49 \pm 6,15$ & $44,76 \pm 3,85$ & $42,14 \pm 4,48$ & \\
\hline
\end{tabular}

Hasil uji Post-hoc LSD Pada kelompok kontrol positif dibandingkan dengan kelompok jus stroberi dosis $3 \mathrm{~g} / \mathrm{kgBB}, 6$ $\mathrm{g} / \mathrm{kgBB}$, dan $9 \mathrm{~g} / \mathrm{kgBB}$ menunjukkan hasil berbeda tidak signifikan. Hal tersebut menjelaskan bahwa jus stroberi dosis 3 $\mathrm{g} / \mathrm{kgBB}, 6 \mathrm{~g} / \mathrm{kgBB}$, dan $9 \mathrm{~g} / \mathrm{kgBB}$ mampu menurunkan kadar SGPT, SGOT, dan MDA tikus yang diinduksi Isoniazid sebanding dengan kontrol positif yaitu Curcumin $p a$ dosis $50 \mathrm{mg} / \mathrm{kgBB}$ tikus. Hal ini menjadi dasar dalam pemilihan dosis efektif jus stroberi bahwa dosis $3 \mathrm{~g} / \mathrm{kgBB}$ merupakan dosis efektif untuk menurunkan kadar SGPT, SGOT, dan MDA tikus.

Isoniazid yang digunakan sebagai induksi dengan dosis $200 \mathrm{mg} / \mathrm{KgBB}$ tikus dapat menimbulkan kerusakan hepar. Kerusakan sel hepar yang terjadi disebabkan oleh metabolit toksik Isoniazid (hydrazine) yang dimetabolisme oleh enzim cytochrome P450 terutama isoform CYP3A4 di hepar (Chen \& Raymond, 2006). Produksi hydrazine yang berlebihan akan membuat hydrazine terakumulasi di dalam hepar dan mengakibatkan peningkatan jumlah produksi radikal bebas (ROS/RNS) yang akan menyebabkan stress oksidatif di hepar (Kumar \& Ramesh, 2014).

Peningkatan jumlah produksi ROS akibat pemberian isoniazid berdampak pada kadar SGPT dan SGOT. Serum Glutamate Pyruvat Transaminase (SGPT) dan Serum Glutamate Oxalacetate Transaminase (SGOT) di dalam darah merupakan indikator kerusakan sel hati. SGPT merupakan enzyme spesifik di hati. Kadar SGPT yang tinggi merupakan indikasi kerusakan hati, kemudian peningkatan SGPT secara signifikan merupakan indikasi kerusakan hati akut (Agrawal et al., 2013). Aktivitas sel yang sangat tinggi dapat menyebabkan kerusakan hepatosit yang selanjutnya terjadi pelepasan enzim tersebut ke dalam aliran darah, sehingga kadar SGPT meningkat (Saraswati, 2015). SGOT dan SGPT akan keluar menuju ekstraseluler dan masuk ke dalam peredaan darah ketika terjadi kerusakan pada sel hepar sehingga terjadi peningkatan kadarnya di dalam darah yang merupakan salah satu diagnosis terjadinya drug induced liver injury (DILI) (Arika et al., 2016)

Peningkatan jumlah produksi ROS akibat pemberian Isoniazid berdampak pada kadar MDA. MDA (malondialdehid) merupakan suatu radikal bebas hasil dari metabolit lipid peroksida. Lipid peroksida terbentuk karena kelebihan produk reactive oxygen specis (ROS) yang menyerang komponen sel (membran lipid dan protein) dengan melibatkan residu asam lemak ganda dari fosfolipid yang sangat sensitif terhadap oksigen (Valko et al., 2007). Jadi semakin tinggi peningkatan produksi ROS akan bedampak pada peningkatan lipid peroksida yang mengakibatkan tingginya kadar MDA pada tikus yang diinduksi isoniazid.

Pada penelitian ini menunjukkan bahwa jus stroberi mampu menurunkan kadar SGPT, SGOT, dan MDA. Hal ini dapat terjadi karena jus stroberi mengandung senyawa flavonoid, alkaloid, tannin, saponin, vitamin $\mathrm{C}$ dan antosianin. Selain itu buah stroberi diduga mengandung senyawa marker quersetin (Aaby et al., 2007). Senyawa-senyawa tersebut yang memiliki peran sebagai antioksidan. 
Flavonoid merupakan antioksidan yang dapat melindungi tubuh dari kerusakan akibat ROS (Reactive Oxygen Species) berperan sebagai scavenger radikal bebas yang berikatan langsung dengan ROS dan meningkatkan aktivitas antioksidan endogen serta sebagai inhibitor aktivitas CYP3A (Wu et al., 2006). Vitamin $\mathrm{C}$ dan tannin yang terdapat dalam jus stroberi memiliki efek sebagai hepatoprotektor dengan bertindak sebagai scavenger radikal bebas yang berikatan langsung dengan radikal bebas ataupun metabolit toksik obat (Hassnin et al., 2013) (Gülçin et al., 2010). Senyawa alkaloid yang terdapat pada jus stroberi (Fragaria ananassa Duchessne) dapat melindungi hepar dari paparan senyawa kimia yang menyebabkan timbulnya radikal bebas (Raj et al., 2010). Senyawa alkaloid juga dapat menghambatan kerusakan oksidatif jaringan pada tikus (Untari et al., 2014). Senyawa saponin juga ikut berperan dalam memperbaiki kerusakan pada hepar serta menurunkan kadar enzim pada hepar (Witthawaskul et al., 2003). Antosianin memiliki aktivitas antioksidan dengan mengkelat ion logam (Miguel, 2011). Quersetin memiliki efek scavenging radikal bebas yang mampu menghambat peroksidasi lipid dan meningkatkan kapasitas antioksidan tubuh (Xu et al., 2019).

Berbagai kandungan di dalam buah stroberi mampu menurunkan kadar SGPT, SGOT, dan MDA. Hal ini dikarenakan kandungan metabolit di dalam buah stroberi berperan aktif dalam melawan radikal bebas (scavenger free radicals), melindungi tubuh dari kerusakan sel, serta memiliki aktivitas antioksidan yang tinggi karena kandungan senyawa fenoliknya yang tinggi.

\section{KESIMPULAN}

Jus stroberi memiliki aktivitas
antioksidan yang berperan sebagai
hepatoprotektor yang mampu melawan radikal
bebas hasil metabolisme isoniazid yaitu
hidrazin dan asetilhidrazin. Pemberian jus
stroberi dapat menurunkan kadar SGPT,
SGOT, dan MDA pada tikus yang diinduksi
isoniazid. Dosis efektif jus stroberi yang dapat
menurunkan SGPT, SGOT, dan MDA adalah
3g/kgBB tikus.

\section{DAFTAR PUSTAKA}

Aaby, K., Ekeberg, D. \& Skrede, G. 2007. Characterization of Phenolic Compounds in Strawberry (Fragaria $\mathrm{x}$ Ananassa) Fruits by Different HPLC Detectors and Contribution of Individual Compounds to Total Antioxidant Capacity. Journal of Agricultural and Food Chemistry, 55 (11): 4395-4406.

Aaby, K., Skrede, G. \& Wrolstad, R.E. 2005. Phenolic Composition and Antioxidant Activities in Flesh and Achenes of Strawberries (Fragaria Ananassa). Journal of Agricultural and Food Chemistry, 53(10): 4032-40.

Agrawal, S. \& Gupta, D. 2013. Assessment of Liver Damage in Male Albino Rats after Repetitive Heat Stress of Moderate Level. National Journal of Physiology, Pharmacy and Pharmacology, 3(2): 147-52.

Arifin, H., Anggraini, N., Handayani, D. \& Rasyid, R. 2006. Standarisasi Ekstrak Etanol Daun Eugenia Cumini Merr. Journal Sains Teknologi Farmasi, 11(2): 88-93.

Arika, W.M., Nyamai, D.W., Osano, K.O. \& Njagi, E.N.M. 2016. Biochemical Markers of In Vivo Hepatotoxicity. Journal of Clinical Toxicology, 6 (297).

Ayala, A., Mario, F. Munoz \& Sandro, A. 2014. Lipid Peroxidation: Production; Metabolism; and Signaling; Mechanisms of Malondialdehyde and 4-Hydroxy-2-None. Oxidative Medicine and Cellular Longevity, 1-31.

Chen, J. \& Raymond, K. 2006. Roles of Rifampicin in Drug-Drug Interactions: Underlying Molecular Mechanisms Involving the Nuclear Pregnane X Receptor. Annals of Clinical Microbiology and Antimicrobials, 5(3): $1-11$.

Departemen Kesehatan RI. 1979. Farmakope Indonesia Edisi III. Jakarta: Departemen Kesehatan Republik Indonesia.

Departemen Kesehatan RI. 1995. Farmakope Indonesia Edisi IV. Jakarta: Departemen Kesehatan Republik Indonesia. 
Endarini, L.H. 2016. Farmakognosi dan Fitokimia. Cetakan Pe. Jakarta: Badan pengembangan dan Pemberdayaan Sumber Daya Manusia Kesehatan.

Giknis, M.L.A. \& Clifford, C.B. 2008. Clinical Laboratory Parameters For Crl:WI(Han) Rats. Charles River Laboratories.

Gülçin, I., Huyut, Z., Elmastaş, M., \& AboulEnein, H.Y. 2010. Radical Scavenging and Antioxidant Activity of Tannic Acid. Arabian Journal of Chemistry, 3 (1): 43-53.

Hassnin, K.M.A. \& Hashem, K.S. 2013. He Hepatoprotective Effects of Vitamin C and Micronized Vitamin $\mathrm{C}$ against Paracetamol Induced Hepatotoxicity in Rats: A Comparative Study. Journal of Veterinary Medical Research, 22(1): 46-52.

Hayati, E.K., Jannah. A. \& Ningsih, R. 2012. Identifikasi Senyawa Dan Akktivitas Antimalaria In Vivo Ekstrak Etil Asetat Tanaman Anting-Anting (Acalypha indica L.). Molecules, 7(1): 20-32.

Kähkönen, M.P., Hopia, A.I. \& Heinonen, M. 2001. Berry Phenolics and Their Antioxidant Activity. Journal of Agricultural and Food Chemistry, 49 (8): 4076-82.

Pillai, K.K., Chidambaranathan, N., Halith, M.M., Jayaprakash, S. \& Narayanan, N. 2012. Hepatoprotective Activity of Cnidoscolus Chayamansa against Rifampicin and Isoniazide Induced Toxicity in Wistar Rats. Research Journal of Pharmaceutical, Biological and Chemical Sciences, 3 (2): 577-85.

Lian, Yong, Jing Zhao, Peiyu Xu, Yimei Wang, Jun Zhao, Li Jia, Ze Fu, Li Jing, Gang Liu, and Shuangqing Peng. 2013. Protective Effects of Metallothionein on Isoniazid and Rifampicin-Induced Hepatotoxicity in Mice. Plos One, 8 (8).

Miguel, M.G. 2011. Anthocyanins: Antioxidant and/or Anti-Inflammatory Activities. Journal of Applied Pharmaceutical Science, 1(6): 7-15.
Mitruka, B.M. \& Rawnsley, H.M. 1981. Clinical Biochemical and Hematological Reference values in Normal Experimental Animal and Normal Humans. $2^{\text {nd }}$ Ed. Year Book Medical Publisher Inc., Chicago. 8183.

Momuat, L.I., Sangi, M.S. \& Purwanti, N.P. 2011. Pengaruh VCO Mengandung Ekstrak Wortel Terhadap Peroksidasi Lipid Plasma. Jurnal Ilmiah Sains, 11(2): 296-301.

Nuria, M.C., Faizatun, A. \& Sumantri. 2009. Uji Aktivitas Antibakteri Ekstrak Etanol Daun Jarak Pagar (Jatropha curcas L.) Terhadap Bakteri Staphylococcus Aureus ATCC 25923, Escherichia Coli ATCC 25922, Dan Salmonella Typhi ATCC 1408. Jurnal Ilmu Pertanian, 5 (2): 26-37.

Oszmiański, J., \& Wojdyło, A. 2009. Comparative Study of Phenolic Content and Antioxidant Activity of Strawberry Puree, Clear, and Cloudy Juices. European Food Research and Technology, 228(4): 623-31.

Peanasari, A.R.I, Djamil, S.L. \& Rohmani, A. 2015. Pengaruh Formalin Peroral Terhadap Kadar SGOT Dan SGPT Tikus Wistar. Jurnal Kedokteran Muhammadiyah, 2: 34-38.

Rahman, A.O., Jarir, A.T. \& Mustofa. 2013. Association of hydrazine and SGPT level two hours after drug administration at the end of intensive phase treatment of pulmonary tuberculosis patients. TMJ., 2(2): 113-122.

Raj, V.P., Chandrasekhar, R.H., Vijayan, P., Dhanaraj, S.A., Rao, M.C, Rao, V.J. \& Nitesh, K. 2010. In Vitro and in Vivo Hepatoprotective Effects of the Total Alkaloid Fraction of Hygrophila Auriculata Leaves. Indian Journal of Pharmacology, 42(2): 99-104.

Reynertson, K.A. 2007. Phytochemical Analysis of Bioactive Constituents from Edible Myrtaceae Fruits. University of New York.

Robinson, T. 1995. Kandungan Organik Tumbuhan Tinggi. ITB Press, Bandung. 
Saraswati, T.R. 2015. Efek Pemberian Serbuk Kunyit Dalam Pakan Terhadap Hepar Puyuh Jepang (Coturnix Japonica). Buletin Anatomi Dan Fisiologi, 23(2): 94-100.

Untari, E.K., Wahdaningsih, S. \& Damayanti, A. 2014. Efek Fraksi N-Heksana Kulit Hylocereus Polyrhizus Terhadap Aktivitas Katalase Tikus Stres Oksidatif. Pharmaceutical Sciences and Research, 1(3): 141-53.

Valko, Marian, Dieter Leibfritz, Jan Moncol, Mark T D Cronin, Milan Mazur \& Joshua Telser. 2007. Free Radicals and Antioxidants in Normal Physiological Functions and Human Disease. The International Journal of Biochemistry \& Cell Biology, 39: 44-84.

Witthawaskul, P, Ampai Panthong, D Kanjanapothi, $\mathrm{T}$ Taesothikul \& $\mathrm{N}$ Lertprasertsuke. 2003. Acute and Subacute Toxicities of the Saponin Mixture Isolated from Schefflera Leucantha Viguier. Journal of Ethnopharmacology, 89: 115-21.
Wu, Yihang, Fang Wang, Qunxiong Zheng, Longxi Lu, and Hongtian Yao. 2006. Hepatoprotective Effect of Total Flavonoids from Laggera Alata against Carbon Tetrachloride-Induced Injury in Primary Cultured Neonatal Rat Hepatocytes and in Rats with Hepatic Damage. Journal of Biomedical Science, 13: 569-78.

$\mathrm{Xu}$, Dong, Meng Jiao Hu, Yan Qiu Wang, and Yuan Lu Cui. 2019. Antioxidant Activities of Quercetin and Its Complexes for Medicinal Application. Molecules, 24(6). 